\title{
Regional Autonomy Implications on Corruption in the Region Indonesia
}

\author{
Subadi Moch. Juli Pudjiono Anik Tri Hariyani \\ Faculty of Law, Merdeka University of Madiun, 79 Serayu Street, Madiun 63133, Indonesia
}

This paper is taken from Higher Education Applied Research (PTUPT), funded by DIPA DRPM, Director General of Research and Strengthening Strength, Kemenristekdikti, Fiscal Year 2019.

\section{Abstract}

Regional autonomy as an effort to accelerate the achievement of the welfare of the people has not been able to meet the expectations of the community and is believed to have negative implications on the increased of corruption cases in the regions. The study of norms supported by indept interviews with experts and legal practitioners of corruption acts has revealed and found that regional autonomy or decentralization in Indonesia has not been matched by the development of a strong legal system, either; legal substance, structure (law enforcement), community legal culture, infrastructure and supervision, so that no matter how strict the level of corruption eradication does not affect the officials in the region to do corrupt.

Keywords: implication, regional autonomy, decentralization, corruption

DOI: $10.7176 / \mathrm{JLPG} / 101-05$

Publication date:September $30^{\text {th }} 2020$

\section{Introduction}

Regional autonomy or decentralization as an effort to accelerate the achievement of people's welfare has been running for almost 20 (twenty) years and has not been able to meet the expectations of the people. Corruption continues to increase and will still be a nation problem that is not easily resolved. ${ }^{1}$ Up to the end of 2014 there have been 325 (three hundred and twenty five) heads and deputy regional heads, 76 (seventy six) members of the House of Representatives (DPR) and the Regional House of Representatives (DPRD), and 19 (nineteen) Ministers and officials of state institutions caught in corruption cases and since the implementation of regional autonomy, about $70 \%$ (seventy percent) of the total heads and deputy heads of the region have been dragged to the green table and the concerns are not thrilling and do not discourage officials other.

On the other hand since the establishment of the Corruption Eradication Commission (KPK) in 2002 until now in 2017 a total of 93 (ninety three) regional heads have become suspects of corruption cases. The condition continues to rise very sharply and based on the records of the Corruption Eradication Commission (KPK) by the end of 2017 has received public reports of 3,747 (three thousand seven hundred and forty seven) indications of corruption in the region. Subsequent developments through the first week of July 2018 The Corruption Eradication Commission (KPK) has conducted Operation Capture Hand (OTT) of 17 (seventeen) corruption cases conducted by officials in the region.

Based on the background description, the problems that will be answered in the study are; 1) How is the development of corruption and efforts to eradicate corruption in the region; 2) What are the implications of regional autonomy or decentralization of corruption in the regions?

\section{Research Methods}

This study uses a normative juridical method that focuses on library research on legislation on local government (regional autonomy), prevention and control of corruption, and other relevant regulations. Research is also supported by data or information obtained from the results of indept interviews with criminal law experts and practitioners of criminal law corruption. Furthermore, the data and information that have been collected are analyzed descriptively qualitative so as to get conclusion and real picture about the development of implementation of regional autonomy and the implication to the increasing of corruption case in region.

\section{Results and Discussion}

\subsection{Development of Corruption Cases in the Regions and Eradication of Corruption}

The implementation of decentralization or regional autonomy has been almost 20 (twenty) years and it turns out that corruption cases are something that can not be avoided. Implementation of regional autonomy may not be imagined will bring negative implications that were never expected by all parties. However, in reality the prevention and severity of efforts to eradicate corruption in the regions is still not as expected by the people.

The regional autonomy program has cut the hierarchical structure of government, so that control of the central

\footnotetext{
${ }^{1}$ Moch. Juli Pudjiono, 2016, "Corruption in the District Between Administrative Errors or Corruption Crime", Yustisia Merdeka, Vol. 3, No. 2, September 2017, P. 67.
} 
government to the regions is no longer effective because there is no direct structural relationship that imposes regional government compliance to the central government. Regional heads, both governors, regents and mayors, are no longer determined by the central government, but by the mechanism of direct regional head elections by the people (direct local elections). Central and regional government relations are only functional, namely only the power to provide policy guidance to local governments without adequate supervision.

The regional legislature failed in carrying out its function as a control institution and on the contrary there was close collusion between the regional government and the DPRD so that control over the administration of regional government became very weak and ineffective. While the control of civil society circles that are highly expected is still very weak. What needs to be underlined is the existence of a control institution such as the DPRD that constitutionally must oversee the policies of the executive (local government) does not mean the opportunity for fraud and corruption to be lost. In fact, when collusion takes place between the executive and the legislature, it is very difficult for the community to exercise control. ${ }^{1}$

According to Saldi Isra, the proliferation of corruption in the region can be seen through three important issues:

1) Consciously or not, the regional autonomy program rolled out by the government only focuses on the delegation of authority in policy making, finance and administration from the central government to the regions, without the sharing of power to the public.

2) The regional autonomy program is not followed by a democratization program that opens up opportunities for community involvement in local government.

3) This decentralization program only provides opportunities for local elites to access regional economic and political resources, which are prone to corruption or abuse of authority. ${ }^{2}$

The negative impact of regional autonomy is the opportunity for individuals in local government to take actions that can harm the State and the people such as corruption, collusion and nepotism. In addition, sometimes there are regional policies that are not in accordance with the state constitution that can cause conflict between regions one with neighboring regions, or even regions with the State, such as the example of implementing the Anti-Pornography Law at the regional level. This is because with the regional autonomy system the central government will be more difficult to monitor the running of government in the region, besides that because indeed with the regional autonomy system, the role of the central government is not very meaningful.

As evidence of the development of corruption in Indonesia both at the Provincial, City and District levels, according to the findings of the Corruption Eradication Commission (KPK) in the presentation of the year-end of performance, can be seen in the table, as follows:

10 Red Zone Corruption Areas

\begin{tabular}{|l|l|c|c|c|l|c|c|}
\hline No. & \multicolumn{1}{|c|}{ Provinsial } & $\begin{array}{c}\text { Community } \\
\text { Report }\end{array}$ & OTT & No. & Provinsial & $\begin{array}{c}\text { Community } \\
\text { Report }\end{array}$ & OTT \\
\hline 1 & DKI Jakarta & 760 & 4 & 6 & South Sumatera & 381 & - \\
\hline 2 & East Java & 564 & 6 & 7 & Riau & 220 & - \\
\hline 3 & West Java & 542 & - & 8 & South Sulawesi & 159 & - \\
\hline 4 & Central Java & 367 & - & 9 & Banten & 158 & - \\
\hline 5 & North Sumatera & 453 & - & 10 & South Kalimantan & 143 & - \\
\hline
\end{tabular}

Source: Corruption Eradication Commission (KPK) 2017-2019.

On the other hand, KPK Chair Agus Hahardja, added that there were many public reports regarding the indication of corruption, indeed it could be attributed to the rampant OTT in the regions. While the number of public reports that have not been followed up, it is still being reviewed and indeed not all reports can be acted upon directly, it still needs to be reviewed and requires time. ${ }^{3}$

In addition to the informations submitted by the Corruption Eradication Commission (KPK), there is still a lot of corruption handled by the Police. Based on the explanation from the Head of the National Police Criminal Investigation Agency (Kabareskrim), that last year (2017) there were 19 (nineteen) hand arrest operations (OTT) by the Corruption Eradication Commission (KPK). Based on Presidential Regulation No. 87 of 2016 has stipulated that the Superintendent of Public Oversight (Irwasum) of the Police as the Head of the Clean Task Force of the Illegal Tap (Satgas Saber Pungli) and Saber Pungli Task Force has also succeeded in arresting 1,340 (one thousand three hundred and forty) Operation Capture (OTT) and it is hoped that it can cause a deterrent/trembling effect and do not just make the extortionists change their mode so that they cannot be captured or illegal and corrupt behavior continues to occur.

Regional autonomy certainly has a positive impact and can promote the region if the people / bodies that make up has a good ability in planning a program and have an analysis of what things will happen in the future.

\footnotetext{
${ }^{1}$ Maria Gabriella, on 3 March 2016, https://prezi.com/nlzixikaezii/korupsi-dan-otonomi-daerah/, accessed 12 November 2017.

${ }^{2}$ Hariyanto Pratomo, http://hadiyantopratomo. blogspot.com/2012/05/otonomi-daerah-dan-menjamurnya-korupsi.html, accessed, 22 Juli 2018.

${ }^{3}$ Komisi Pemberantasan Korupsi, 2018, End Note of 2017 KPK, Jawa Pos, Jakarta, January 25, 2018 , P. 1.
} 
But on the contrary will have a negative impact if the people / agencies that make up the program is less understanding or less know about how to plan well and analysis of the impact that will happen is arbitrary and corruption that can not be controlled again.

Based on the above description and KPK data, it is clear that the development of corruption in the region is still very high, in other words the last 5 (five) years of the implementation of regional autonomy or the decentralization of corruption crime continues to be high and the trend tends to rise, as can be seen in graph, following:

Trends in suspects of Regional Head (2015-2019)

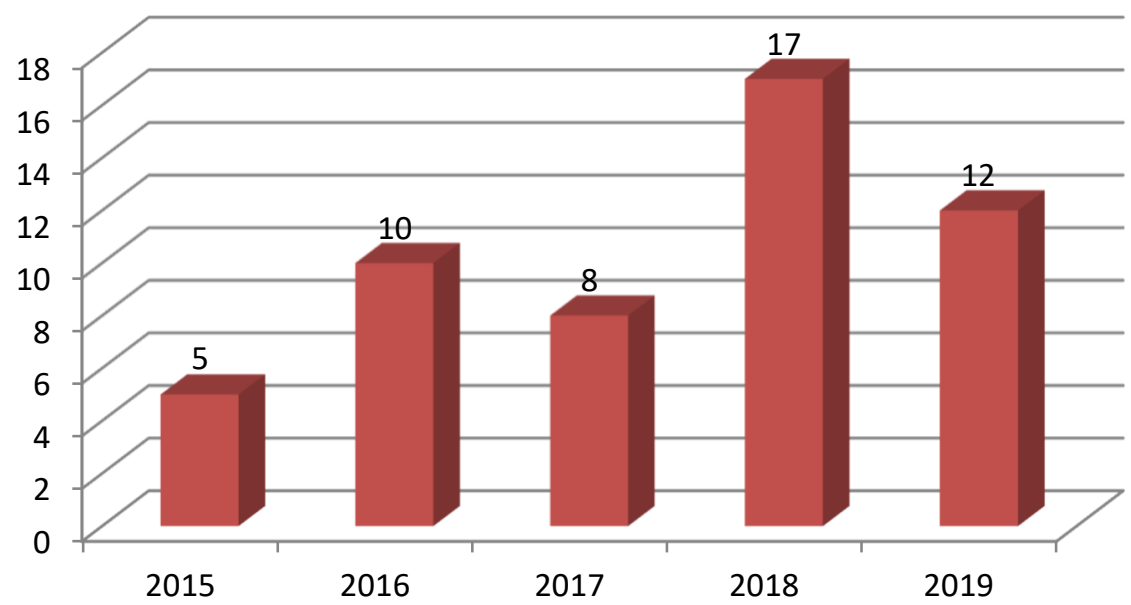

- Suspect

Source: Corruption Eradication Commission (KPK) Year 2015-2019 are processed.

Looking at the graph, it seems clear that in 2018 the regional head of the Governor, Bupati or Mayor and the Head of Office involved in non-criminal acts of corruption turned out to be very sharp. Within the period of January to the end of July 2018 the Corruption Eradication Commission (KPK) has succeeded in carrying out a hand-arrest operation (OTT) and has named a suspect against 17 (seventeen) regional heads and / or heads of departement.

The amounts mentioned above are many who believe that they will continue to grow and concerning them as suspects together with their representatives. Moreover, it is also a candidate for Regent or Mayor and Governor to be elected in the simultaneous elections on June 27, 2018. In addition to the corruption cases described above, it has also been found that many cases of illegal levies (levies) committed by government employees may enter the realm of corruption, but if the value is only Rp.100.000,00 up to Rp.200.000,00, what corruption should be taken, whereas the budget for criminal prosecution of corruption is also limited. In this case it may be necessary that internal law enforcement and can be imagined if all the perpetrators go to jail, then the cost or budget required State will be very large and if it is done a lot of State money to be spent. According to Kabareskrim Polri may be required restorative justice concept State or money corruption results by the perpetrators without imprisonment can be applied to small-scale levy. ${ }^{1}$

Observing this fact, it must be admitted honestly that the Corruption Eradication Commission (KPK) has worked hard in eradicating corruption, but it turns out that the number of corruption cases has also not diminished. Thus the challenges in eradicating corruption are also increasingly severe and the need for a breakthrough in the prevention of corruption for awareness, that ${ }^{2}$ :

1) Eradication of corruption is not possible only by a repressive approach.

2) The prevention concept developed by the KPK has not been based on an integrated, basic and integrated concept.

3) Eradication of corruption should stand at the same time oriented to the formation of values-based character, which is approached systematically and system development.

4) Policies that are then supported by rules and legislation are still not sufficient for the process of building a system.

5) The initiatives and breakthroughs taken by the Government are still very few and even if they have not been done in an integrated manner.

\subsection{Implications of Decentralization or Regional Autonomy against Corruption in Regions}

Regional autonomy or decentralization is an appropriate choice in an effort to accelerate the achievement of

${ }^{1}$ Ibid.

${ }^{2}$ A. Rachim, Dedie, 2012, Policy on Eradicating Corruption in Accelerating the Eradication of Corruption in Indonesia, Paper, Presented in Anti-Corruption Education Training of Trainers for Universities, Director of Dikyanmas KPK, Surabaya, 24 June 2014. P.10. 
welfare rakayat. As explained by Rodnelli, that with decentralization or regional autonomy, efforts towards poverty alleviation, equal distribution of people's welfare through the pro-active role of community groups are possible to be carried out more effectively. Still in the same context Conyers explained, that; decentralization, community commitment to change social, economic, and political attitudes and behavior can be optimized, because basically they themselves plan, implement, control development with facilities that come from the local government itself.

On the other hand corruption and power are often likened to two sides of the coin, namely corruption always accompanies power and vice versa power is the entrance to the occurrence of corruption. As explained by Lord Acton, professor of modern history at Cambridge University, stated that; "Power tends to corrupt, and absolute power corrupt absolutely". From adigium it can be explained that corruption will always follow the nature of power, as happened during the all-centralized New Order era, corruption only occurs in the central power and vice versa in the era of regional autonomy or decentralization, corruption also occurs in many regions.

Decentralization or regional autonomy that gives authority to local governments to plan, implement, control their own development, in other words the regions are authorized to take care of their own households. Law Number 23 Year 2014, states that: The People's Legislative Assembly (DPRD) and the regional head shall be domiciled as local government administrators who are mandated by the people to carry out government affairs submitted to the Regions. DPRD and regional heads domiciled as partners of this law as a whole parallel to have a function to facilitate the arrangement in an integrated manner. The regional head carries out the implementation function of the Regional Regulation (hereinafter referred to as the Regional Regulation) and the Regional policy while the DPRD has the function of forming Local Regulations, budgets (budgeting) and controlling (controlling). ${ }^{1}$

It is in this context that problems begin to arise, in which regions are authorized to elect their own regional heads. In the practice of direct election of regional head (Pilkada) directly requires high cost politics for a candidate head of region, even for candidate Mayor / Regent must prepare minimum 30 (thirty) billion and candidate of Governor must prepare at least 100 (hundred) billion rupiah. The candidates for regional heads tend to think rationally and precisely and to achieve the goal of winning the election of regional head candidates not infrequently have been using any means of money politics and other forms of lawlessness.

Furthermore, after being elected head of the region (Regent, Mayor, and or Governor) in general they will also think prakmatis also to be able to restore the political costs that have been issued during the election of regional heads in various ways, ranging from abuse of authority to benefit or enrich themselves in ways that violate the law or commit a criminal act of corruption.

Based on monitoring in several regions at the time of the regional head elections (Pilkada) there had been a lot of money politics and several corruption cases in the same area, it turned out that it was clearly revealed that the suspect of the regional head had been proven to abuse his authority to enrich himself by breaking the law or acting criminal corruption.

Observing the reality or reality of increasing corruption from year to year and the rigors of government efforts to prevent and tackle corruption through the Corruption Eradication Commission (KPK), Attorney General's Office, Police, it seems very difficult to reject the opinion or opinion which states that regional autonomy or decentralization is good or indirectly has negative implications for increasing corruption in the region.

\section{Conclusion}

Based on the description of the background of the problem can be concluded as follows:

1. Whereas since the implementation of regional autonomy or decentralization, corruption cases have plagued the regions and from year to year tend to increase. The establishment of a new Corruption Eradication Commission (KPK) in 2002 as an effort to prevent, overcome and eradicate corruption is actually a quite strategic step, but amidst the harsh efforts made by the Corruption Eradication Commission (KPK), the Prosecutor's Office and the Police have not been able to resolve corruption in area but still increasing.

2. Whereas the implementation of regional autonomy or decentralization and the rigor of the Corruption Eradication Commission (KPK), Attorney General's Office, Police in an effort to eradicate corruption, it seems very difficult to reject the opinion or opinion that regional autonomy or decentralization has direct or indirect implications. increasing corruption in the region. has implications for increasing corruption cases in the region.

\section{REFERENCES}

Dedie, A. Rachim, 2012, "Policy on Corruption Eradication of Corruption Eradication Strategy in Indonesia", Paper, Presented at the Training of Trainers of Anti-Corruption Education for Higher Education, Direktur Dikyanmas KPK, Surabaya, 24 Juni 2014.

Gabriella, Maria, on 3 March 2016, https://prezi.com/nlzixikaezii/korupsi-dan-otonomi-daerah/, accessed, 12

\footnotetext{
${ }^{1}$ Agus, Kusnadi, "Re-evaluation of Central and Regional Supervision Relations After the enactment of Law No. 23 of 2014 concerning Regional Government " , Arena Hukum, Vol. 10, No. 1, April 2017, P. 62.
} 
November 2017.

Komisi Pemberantasan Korupsi, 2018, Catatan Akhir KPK 2017, Jawa Pos, Jakarta, tanggal 25 Januari 2018.

Kusnadi, Agus, "Re-evaluation of Central and Regional Supervision Relations After the enactment of Law No. 23 of 2014 concerning Regional Government ", Arena Hukum, Vol. 10, No. 1, April 2017.

Pratomo,Hariyanto,http://hadiyantopratomo.blogspot.com/2012/05/otonomi-daerah-dan-menjamurnyakorupsi.html, accessed, 22 Juli 2018.

Subadi, 2010, Tenure and Use of Forest Land (Toward Sustainable, Sustainable, and Sustainable Land Use and Utilization in the Era of Regional Autonomy),Prestasi Pustaka Publiser, Jakarta.

https://ferli1982.wordpress.com/2012/08/13/ corruption-in-area strategy/, accessed, 12 Juni 2018. 